\title{
Estimation of compressive strength based on Pull-Out bond test results for on-site concrete quality control
}

\author{
Estimativa da resistência à compressão a partir de \\ resultados de ensaios de aderência tipo Pull-Out para \\ controle da qualidade do concreto na obra
}
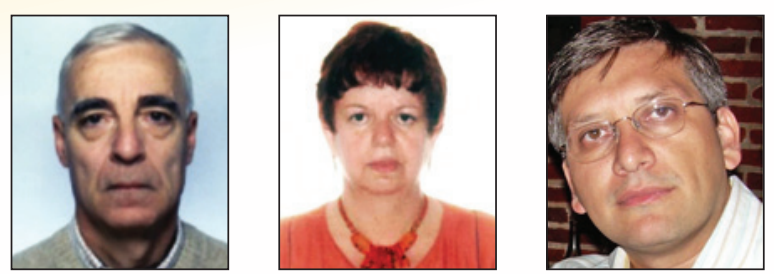

M. S. LORRAIN a

michel.lorrain@insa-toulouse.fr

M. P. BARBOSA b

mbarbosa@dec.feis.unesp.br

L. C. P. SILVA Fo

Icarlos66@gmail.com

\begin{abstract}
Quality control of structural concrete has been conducted for several decades based mainly on the results of axial compression tests. This kind of test, although widely used, is not exempt from errors and has some considerable drawbacks that may affect its reliability, such as the need for appropriate and careful specimen conditioning and adoption of adequate capping techniques. For these reasons, it would be useful to have complementary or alternative ways to check compressive strength, in order to improve concrete quality control. The use of a bond test to monitor concrete strength is being proposed by an international group of researchers from France, Tunisia and Brazil as a potential means to this end. Given the fact that the link between bond resistance and concrete strength is already well established, this type of test seems to be a viable alternative to traditional methods. Nonetheless, to check if the underlying principle is sound when used in different circumstances, the group has been gathering data from several studies conducted by different researchers in various countries, with distinct concretes and rebar types. An analysis of the data collected shows that there is a clear and strong correlation between bond resistance and compressive strength, no matter the influence of other variables. This result validates the basic idea of using an Appropriate Pull-Out (APULOT) bond test to assess concrete strength. If the general principle is valid for random data obtained from different studies, the definition of a clear and appropriate test will probably lead to the reduction of experimental noise and increase the precision of the strength estimates obtained using this method.
\end{abstract}

Keywords: bond stress, concrete compressive strength, quality control of concrete, pull-out test.

\section{Resumo}

O controle de qualidade do concreto estrutural vem sendo realizado, há várias décadas, baseado principalmente nos resultados de ensaios de compressão axial. Este tipo de ensaio, embora amplamente utilizado, não está isento de erros e tem algumas desvantagens consideráveis que podem afetar sua confiabilidade, tais como a necessidade de condicionamento adequado e cuidadoso dos corpos-de-prova e de adoção de adequadas técnicas de nivelamento e capeamento. Por estas razões, seria útil ter maneiras complementares ou alternativas para verificar a resistência à compressão, a fim de melhorar o processo de controle de qualidade do concreto. O uso de um ensaio de arrancamento para monitorar a resistência do concreto está sendo proposto por um consósrcio internacional de pesquisadores da França, Tunísia e Brasil como um meio potencial de atingir essa meta. Dado que a existência de uma relação direta entre a tensão de aderência e a resistência do concreto já está bem estabelecida, este tipo de teste parece ser uma alternativa viável aos métodos tradicionais. No entanto, para verificar se o princípio subjacente é valido quando usado em diferentes circunstâncias, o grupo tem buscado recolher dados de vários estudos, realizados por diferentes pesquisadores, em diversos países, com concretos e barras de armadura de distintos tipos. Uma análise dos dados coletados confirma que há uma correlação clara e um forte vínculo entre a tensão de aderência e a resistência à compressão, independentemente da influência de outras variáveis. Esses resultados validam a idéia básica de usar um teste de Pull Out adequado (denominado APULOT) para avaliar a resistência do concreto. Se o princípio geral é válido para dados aleatórios obtidos em diferentes estudos, a definição de um procedimento de teste claro e adequado provavelmente levará à redução erros experimentais e aumentará a estimativa da precisão obtidas por esse método.

Palavras-chave: tensão de aderência, resistência à compressão do concreto, controle de qualidade do concreto, teste de pull-out.

Professor, Institut National des Sciences Apliquées de Toulouse, michel.lorrain@insa-toulouse.fr

Professor, São Paulo State University, Department of Civil Engineering, mbarbosa@dec.feis.unesp.br.

Professor, Federal University of Rio Grande do Sul, Civil Engineering Graduate Programme (PPGEC), Icarlos66@gmail.com 


\section{Introduction}

Quality control of structural concrete is a vital step of the building process, necessary to ensure that user needs and design requirements are met. An adequate quality control strategy enables time and money savings, giving opportunity for the constructor to obtain gains by means of a swifter turnover of formwork or by the earlier removal of shoring structures in multi-floored buildings, among other measures.

The most common and often unique quality indicator used for concrete elements is compressive strength. Therefore, results of axial compressive tests performed on samples taken during concrete placement are usually critical to check fulfillment of design assumptions and contractual obligations.

Despite the fact that axial compression tests are widely known and used, there are still some doubts about the reliability of assessments done based solely on this kind of data. The results obtained from axial compression tests sometimes do not represent well the actual concrete resistance, because samples are not subjected to the same curing conditions, load and stress states than structural elements. Furthermore, inadequate test preparation and lax execution practices tend to happen with certain frequency, increasing variability and affecting the trustworthiness of strength estimates. Given that a reliable assessment of the attainment of a specified compressive strength is vital and may greatly influence cost and safety, it would be quite useful to have supplementary or alternative ways to check concrete compressive strength, in order to improve quality control. This would increase the level of confidence on the assessment and help prevent possible structural failures, or at least avoid the costly and maybe unnecessary repair or demolition operations that are poised to be undertaken when low strength estimates are obtained.

An international research consortium, established between research groups from France, Tunisia and Brazil, has been working on the development and advancement of an idea proposed by Prof. Michel Lorrain, which consists of using bonding tests to complement or replace axial compressive test data, in order to estimate concrete strength. To this end, an appropriate pull-out bond test, named APULOT, conceived to be easy to perform, reliable and low-cost, is under development. To ensure that this kind of initiative is worth pursuing, it was considered necessary by the APULOT research group to double check the validity of the correlation between compressive strength and bond resistance, for various concrete and rebar types. Therefore, a survey of experimental data collected from several experimental programs, performed by distinct researchers, in different countries, was carried out. The idea was to verify if the correlation between compressive strength and bond resistance would be shown to be as robust as expected. The positive results obtained indicate that the use of the APULOT test as a supplementary or alternative way to monitor compressive strength of structural concrete may be a feasible and useful alternative to improve concrete quality control.

\section{Using axial compression tests for concrete quality control}

Since the first modern Building Code, the French "Circulaire de 1906", published in 1906 [1], it has been a established practice that the quality of structural concrete would be inferred by the results of axial compression tests performed on samples taken during concrete casting

The axial compression test is normally done following procedures given by standards such as the European EN 12390 [2] and the Brazilian NBR 5739 [3], or standard practices such as the one provided in the ACl 214.4R-03 - Guide for Obtaining Cores and Interpreting Compressive Strength Results [4]. These standards and guidelines define specimen shape and geometry; describe preparation and conditioning techniques; specify testing equipment and test procedures; and make considerations about result analysis. All of them also give plenty of advice about sources of errors and details that need to be taken into account to ensure that results are reliable.

In general, axial compression tests are well accepted and widely used. They have become the preferred way to assess concrete quality because they offer some obvious advantages:

- the test procedure is not very complex;

- results are relatively straightforward and easy to interpret;

- the data obtained, expressed in terms of maximum normal compressive stress for crushing failure, can be directly implemented in calculations of resisting forces (normal force, bending moment), which are used to assess the safety of structural elements;

- compressive strength results have been shown to be fairly correlated to several other mechanical properties, such as tensile strength, shear strength, bond strength, deformation modulus;

- there is an ample and worldwide experience on use of this test and this know-how helps reduce errors and variability.

But the tendency to rely solely on axial compression tests for concrete quality control has been increasingly criticized because of some shortcomings of these tests, such as:

- concrete is not an homogeneous material. Therefore, the "axial compression test", which actually is an axial shortening test, does not produce a pure compressive stress distribution and the results of the test represent only a conventional and theoretical situation. In fact, the meaning of the results, in terms of actual structural performance, is not so easy to interpret;

- because concrete is becoming more and more resistant, due to better mix and casting practices, crushing forces have also increased and some of the older testing machines cannot be used anymore to perform the test. Newer, more sophisticated and expensive testing machines, with stiffer frames, are often needed in order to handle high strength concrete (HSC) or very high strength concrete (VHSC) samples. Furthermore, it is necessary to install protections against explosive fragments and, sometimes, to replace the traditional steel plates with sand boxes. Therefore, it can be argued that the testing procedure nowadays is not so simple as before;

- to obtain good results specimens have to prepared and capped carefully. In order to have smooth and parallel faces, one or both their ends must be grounded of finished with mortar, since sulphur-based coatings are no longer allowed in several countries. Grinding is becoming the accepted practice but it is still not possible in many laboratories, which do not possess adequate grinding machines. Even where these expensive machines are available, adequate training is necessary to ensure that they are correctly used, specially when dealing with HSC or VHSC, when grinding might be a time consuming and delicate operation; 
In short, it can be said that axial compression tests are undoubtedly the main reference used today to assess compressive strength for concrete quality control. Unfortunately, they are not exempt from drawbacks. Given the importance of reliable compressive strength estimates to check design calculations and certify material quality, improvements would be welcomed, especially because traditional tests are becoming progressively more difficult to perform and more expensive. There is a window of interest, therefore, to justify the investigation of bond tests as a way to enhance structural concrete quality control, as discussed ahead.

\section{Using bond tests to assess concrete compressive strength}

The bond mechanism between concrete and reinforcement bars has been vigorously investigated since the very inception of reinforced concrete buildings. Gallus Rehm, one of the first researchers to work on the theme, performed a systematic investigation of bond mechanisms, including a thorough and well-structured analysis of rib-bearing forces [5]. Based on his contribution, deformed bars started to be characterized by rib height, inclination, width and a roughness coefficient. In time, the concept of relative rib area $f_{R}$, used to encompass these various influences, was defined and is currently used to classify bars in various standards, inclusive the Eurocode 2 [6].

Due to the importance of steel-concrete bonding to structural performance, several international associations such as ACI, RILEM and the FIB/CEB have instituted task groups to gather and consolidate knowledge on the bond mechanisms in reinforced concrete. In fact, since 1957, when RILEM organized, in Stockholm, the first Symposium on Bond and Crack Formation in Reinforced, the steel-concrete bond mechanism have been extensively analyzed and described. Over the years it was demonstrated that several factors influence bond resistance, such as:

- bar roughness;

- embedded length;

- concrete cover thickness;

- casting position;

- loading conditions (rate of application, sustained loads, cycles,...)

- vibration;

- concrete mix composition (additives, LWC, HSC, SCC, ...)

Nonetheless, it was noticed that concrete strength is always a determining factor on bond resistance and several Building Codes have incorporated relationships between these mechanical properties. For instance, the French standard BAEL 91, revised in 1999 [7], establishes that the ultimate bond stress $\tau_{\text {su }}$ might be given as:

$$
\tau_{s u}=0,6 \cdot \psi_{s}^{2} \cdot f_{t j}
$$

with $\psi_{\mathrm{s}}=1$ or 1.5 for smooth or deformed bars, respectively, and with the concrete compressive and tensile characteristic stresses $\left(\mathrm{f}_{\mathrm{cj}}\right.$ and $\mathrm{f}_{\mathrm{t} j}$, respectively) correlated by expression (2), when $f_{c j} \leq 60 \mathrm{MPa}$ :

$$
f_{t j}=0,6+0,06 f_{c j}
$$

or by expression (3), when $60 \mathrm{MPa} \leq \mathrm{f}_{\mathrm{cj}} \leq 80 \mathrm{MPa}$

$$
f_{t j}=0.275 f_{c j}{ }^{2 / 3}
$$

Meanwhile, the Eurocode 2 [6] gives the following expression for the anchorage ultimate bond stress in reinforced concrete:

$$
f_{b d}=\left(2.25 f_{c t k 0.05}\right) / \gamma_{c}
$$

where $f_{\text {ctk0.05 }}$ is the compressive strength of concrete and $\gamma_{c}$ a partial safety factor

The Brazilian standard NBR 6118/2003 [8] uses a similar approach as the one used in the CEB recommendation RC6: Bond Test Reinforcement Steel: Pull Out Test [9] to calculate the bond resistance $f_{b d}$ from the compressive strength of concrete $\left(f_{c t d}\right)$ adjusted by coefficients $\eta 1$ (=2,25 for deformed bars), $\eta 2(=1,0$ in case of fairly good bond conditions) and $\eta 3(=1,0$ for $\Phi<32 \mathrm{~mm})$, as seen in expression (4):

$$
f_{b d}=\eta_{1} \cdot \eta_{2} \cdot \eta_{3} \cdot f_{c t d}
$$

It is interesting to notice that although significant research was carried out on concrete-rebar bond, there is not yet a standardized bond test recognized internationally. Several bond test configurations have been proposed and tested, by different researchers and organizations, such as the ASTM [10], the RILEM/CEB/FIB [11] and the $\mathrm{ACl}$ [12], using different experimental setups: push out, pull out, bending tests, beam test, etc.

The common principle in all bonding test configurations is to force a bar embedded in the concrete to slip. Concrete splitting failures may occur if enough confinement is not provided. According to RILEM recommendations for the pull-out test, the simplest and most widely used bond test, when bar slipping occurs, the bond strength is represented by the mean ultimate mean bond stress at the moment of the bond-slip failure, as given in expression (5):

$$
\tau_{m}=\frac{F}{\pi \Phi l}
$$

with $\mathrm{F}$ as the pulling force at bond-slip failure, $\Phi$ the bar diameter and $I$ as the interface length.

Independently of the configuration, bond tests arguably have some disadvantages, in relation to compressive tests, when used for concrete quality control:

- they are not so easy to perform;

- the experimental procedures are so varied and numerous that it is difficult to choose the best bond test;

- the result depends on the concrete strength and on the bar roughness;

- the results are said to be scattered and not reliable, because 
failure mode can vary from splitting of concrete cover to bondslip failure or bar yielding or buckling;

Most of these problems can be overcome by the definition of a standard test procedure, performed on a specimen conceived to ensure bond-slip failure. Furthermore, there might also be some advantages in using bond tests to assess compressive strength, which often are not emphasized:

- reinforced concrete is a composite material. This fact is not taken into account in the traditional axial compressive tests but is inherent to the very nature of bond tests;

- lower forces are necessary to reach the failure point in bond tests (around 20 times less than for crushing in compression), even for HSC or VHSC, which allows the use of simpler and lighter loading frames and equipments;

- bond strength is correlated to concrete compression strength, as already mentioned among the axial compression test advantages;

- in some cases, the testing procedure and the preparation of the specimens can be even less sophisticated and expensive than the ones used for axial compressive tests.

Hence, the idea of conceiving an appropriate bond test that can be used to easily check concrete compressive strength, allowing on-site quality control of structural elements, seems to be justified. That is one of the main aims of the APULOT research group.

\section{Developing an appropriate bond test for on site concrete quality control}

To demonstrate that a very strong correlation can be found between ultimate bond stress and compressive strength, data ob- tained from different researches was collected and combined by the researchers involved in the APULOT project. Figure 1 shows a graph created with the data obtained from LORRAIN et al [13], TAVARES [14], BARBOSA [15] and ALMEIDA [16]. It is important to highlight that only results where the bond-slip failure mode was obtained were used to create the graph. Results where concrete splitting failure was recorded were discarded.

The analysis of figure 1 indicates that there is a clear linear relationship between ultimate bond stress (in $\mathrm{MPa}$ ) and concrete compressive strength (in $\mathrm{MPa}$ ), which provides a strong argument for the idea of using bonding tests to estimate compressive strength.

As shown in Figure 2, created only with the data from LORRAIN et al [13], the idea would be to estimate strength from bonding results, using a correlation function. This simple reverses the way that the relationship is normally incorporated on many building standards, where bond strength is estimated from compressive strength, to check the necessary embedment lengths of rebar during design calculations, as discussed before.

It is interesting to notice that the relationship between bond stress and compressive strength is consistent over time. This means that results from tests performed at different ages can be combined to create the relationship model. However, the use of a bond test at 7 days will naturally provide an estimate of the concrete compressive strength at the same age. Formulas proposed by different Building Codes can then be used to adjust the estimate to the standardized compressive strength for the age of 28 days $\left(\mathrm{fc}_{28}\right)$. Preliminary results from the APULOT group have shown that results of bond tests performed at 7 days can be used successfully to estimate $\mathrm{fC}_{28}$ with a fair degree of confidence, as shown by VALE SILVA [17] Despite the clear correlation seen in Figures 1 and 2, there is still

Figura 1 - Concrete compressive/bond strength correlation with data from (11) (12) (13) (14)

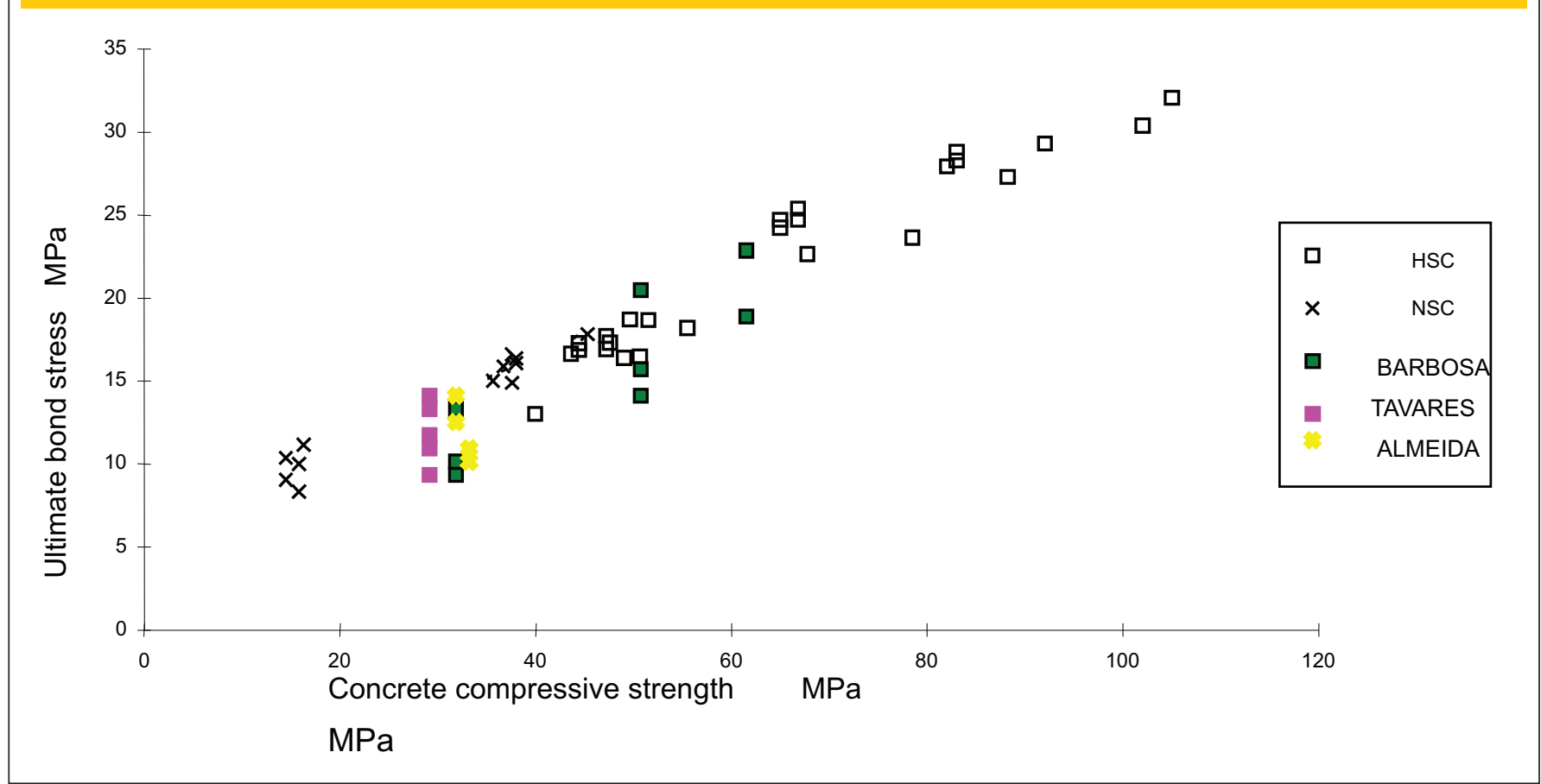


Figura 2 - Example of the principle of concrete compressive strength estimation from bond strength results. (Source: Lorrain et al (13))

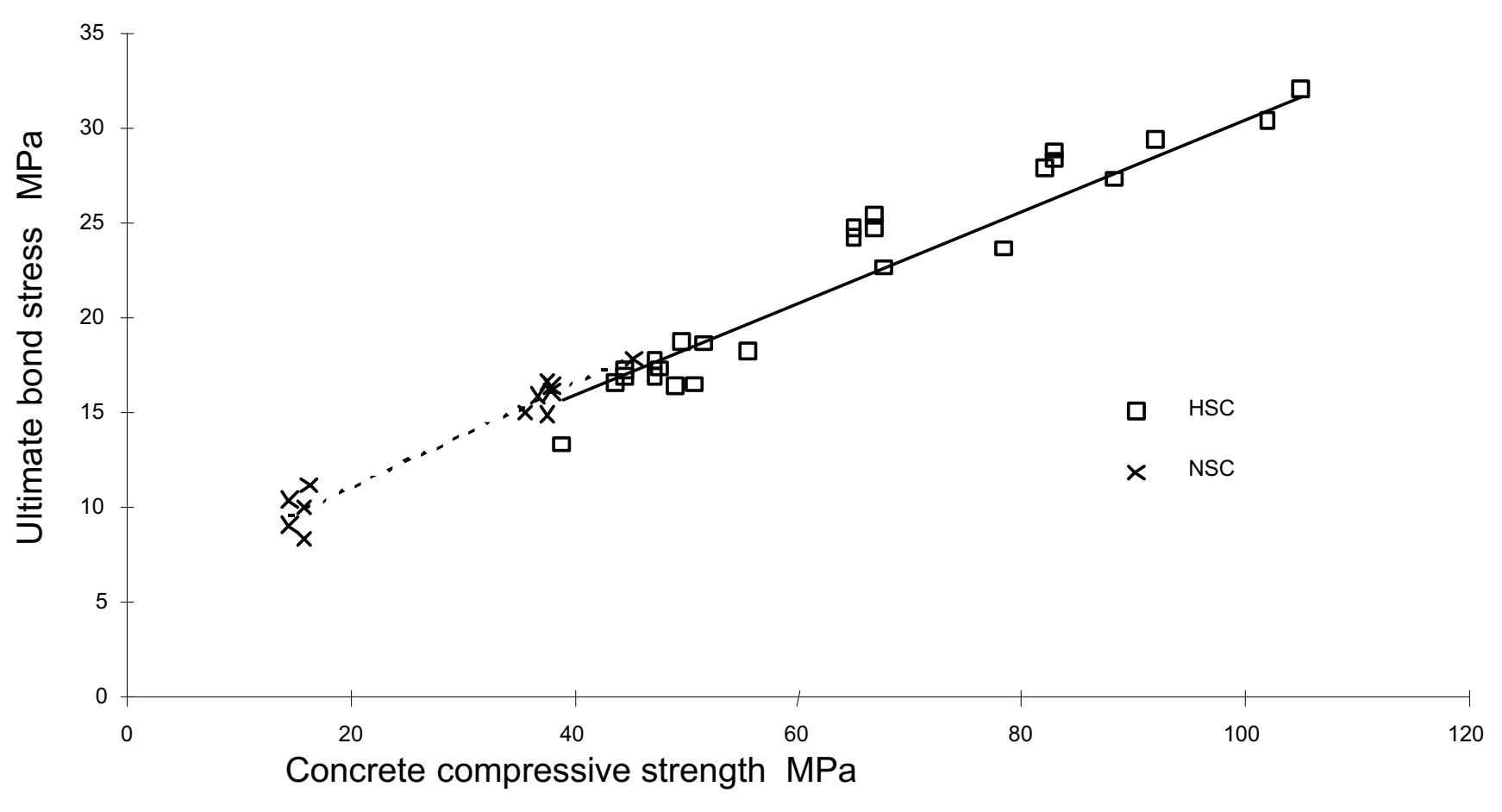

a considerable degree of variability on the data, because in some cases similar bond stress values have been associated with a fairly large range of compressive strength results.

The APULOT research group believes that a large part of this variability might be attributed to varying specimen and test condition, given that the results used to create figures 1 and 2 where obtained in different countries, using bars with distinct geometries and sizes, tested under non-standard conditions. If a clear relationship can be obtained in these far from favorable and non-controlled conditions, is can be argued that a much better estimate model might be developed if a standard test procedure was established.

This perception led to the development of a proposal for a standard bond test for concrete control, which was named APULOT ( $A p$ propriate Pull-Out) bond test, which is still under consolidation, but has shown good promise, as described ahead.

\subsection{Requirements for an appropriate bond test}

To be appropriate for on-site control, the proposed bond test should fulfill the following requirements:

- be easy to perform even in unfavorable conditions, such as poorly equipped and non-controlled worksites;

- be cheap enough to be used as widely as possible;

- be reliable;

- trigger only the bond-slip failure mode.

Among the different configurations used for bonding tests, the Pull Out Test (POT) type, formalized in the RILEM RC-6 recommendation [9], is clearly one of the most simple, consistent, cheap and easy to carry out ways to perform bond tests. Therefore, this configuration was chosen as the basis for the development of the APULOT test.

A review of the literature regarding POT results, specially the data recorded for more than 30 years in the Civil Engineering Department INSAT, shows that the adoption of a 1/10 ratio between bar diameter and concrete thickness provides a specimen with a geometry that ensures that the failure mode will be by slipping, avoiding the splitting failure of concrete. The use of a slight lateral restraint helps to ensure this behavior, as confirmed by FEM analysis and experimental investigations [18].

Having this in mind, the APULOT test configuration was established considering that a plastic mould (a PVC tube or a discarded plastic bottle) adequately adjusted could be used to cast the specimen and would be left in place for the test. The specimen would be formed therefore by a roughly cylinder shaped concrete mass with a single rebar segment inserted in the middle, with both ends protruding from the concrete. The sketch in Figure 3 shows the general principle of the APULOT test, while Figure 4 shows how a discarded plastic bottle could be recycled to be use as a mould for the proposed APULOT test.

This idea of using discarded plastic bottles was pursued to demonstrate that the test could be performed under real worksite conditions and to help reduce the environmental impact by avoiding using new PVC tubes as moulds. Vale Silva et al [19] have studied several types of plastic bottles and demonstrated that they most of them can be used as moulds with very good results, provided that the $1 / 10$ relationship between minimum concrete diameter and 


\section{Figura 3 - Schematics of the appropriated pull out test in development for on-site concrete quality control}

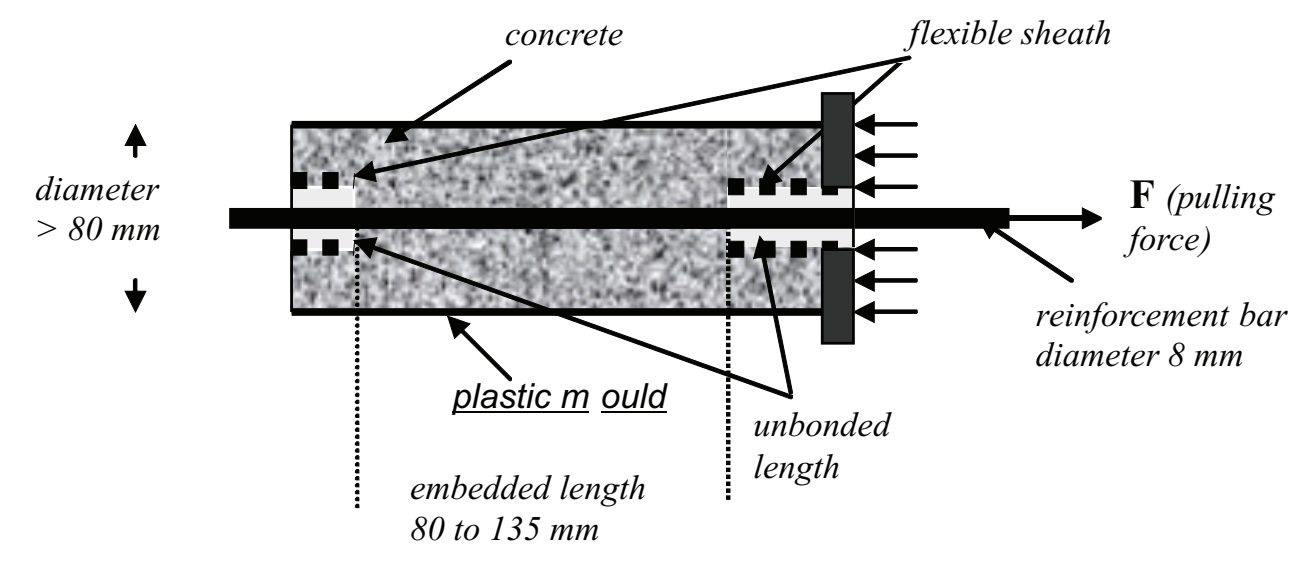

rebar size is maintained. To ensure this, the APULOT group is considering the use of an $8 \mathrm{~mm}$ rebar for the standard test procedure under consolidation, because this bar size means that the $1 / 10$ rate will be obtained, and therefore bar slipping failure mode will be predominant when $100 \mathrm{~mm}$ PVC tubes or any $1,5 \mathrm{I}$ or bigger plastic bottle are used as moulds.

\section{Experimental verification of the APULOT test concept}

In order to check the feasibility and robustness of the proposed APULOT concept two independent experimental sets of tests were conducted at the Civil Engineering Department of ENI GABES (ENIG), in Tunisia; and at INSA TOULOUSE (INSAT), in France.
Both used the APULOT test setup but were carried out using different and non-related concrete mixes. The idea was to familiarize more researchers with the APULOT test but it also provided the opportunity to collect more data, at different concrete strength levels, and check how it would fit with the data already gathered by some members of the group.

\subsection{Experimental Procedures}

For the feasibility studies described in this paper, bond-test cylindrical specimens were molded using recycled mineral water plastic bottles, adopting the greener approach to the APULOT test. Given that the minimum diameter on the central part of the bottles (where the inserted bar is actually bonded to the concrete)

\section{Figura 4 - Use of discarded plastic bottles as recycled moulds for casting an APULOT specimen}

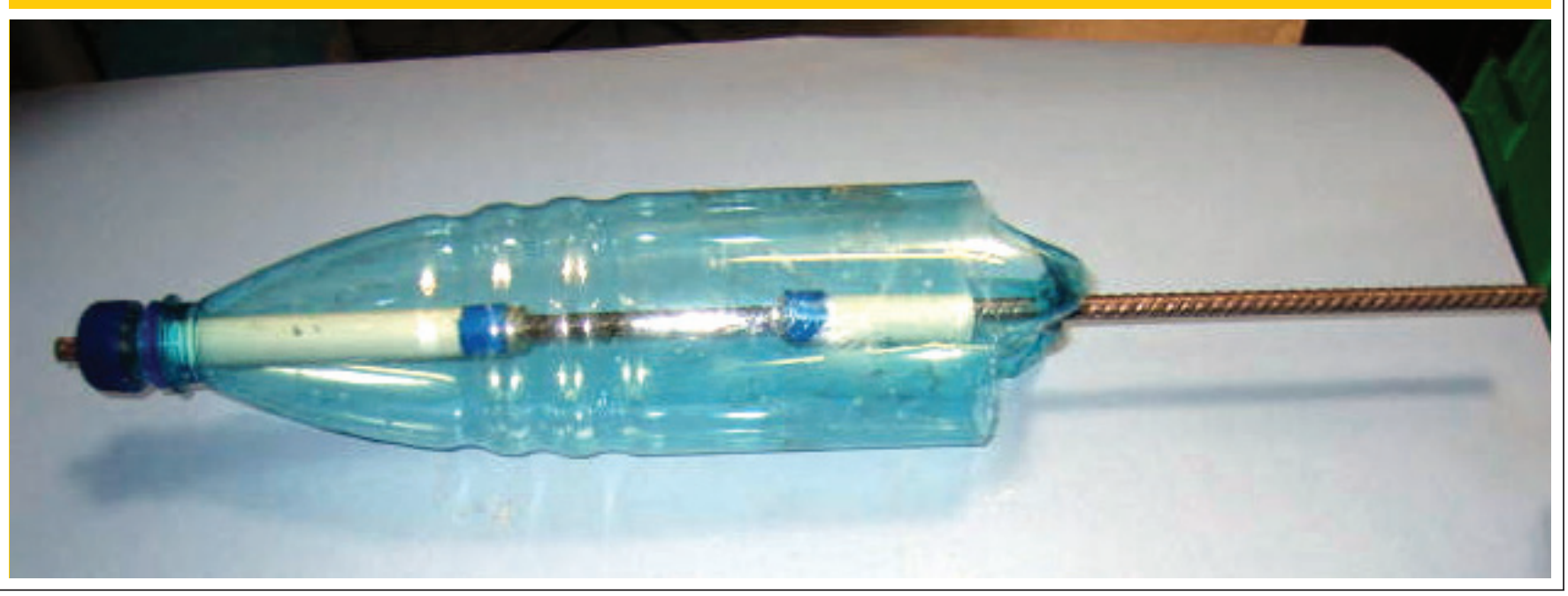




\section{Table 1 - Concrete mixes used in the studies at ENIG and INSA}

\begin{tabular}{|cccc|}
\hline \multicolumn{2}{c}{ concrete mix ENIG, $\mathrm{kg} / \mathrm{m}^{3}$} & \multicolumn{2}{c|}{ concrete $\mathrm{mix} \mathrm{INSAT,} \mathrm{kg} / \mathrm{m}^{3}$} \\
\hline cement (CEM I 32.5) & 250 & cement (CEM I 42.5) & 400 \\
water & 150 & water & 230 \\
sand & 750 & river sand & 652 \\
aggregate & 1050 & aggregate & 1265 \\
\hline
\end{tabular}

was slightly larger than $80 \mathrm{~mm}$, an $8 \mathrm{~mm}$ rebar was used, in order to ensure that the slipping failure mode was dominant. To further prevent the splitting failure of concrete, the plastic bottles used as moulds were not removed for the test, which provided some additional lateral constraint.

To define the bonded zone and avoid stress concentrations, parts of the rebar on both sides of the specimen were inserted inside plastic caps, defining a central bonded zone. The embedded length used varied between $80 \mathrm{~mm}$ and $135 \mathrm{~mm}$, because the researchers wanted to check how this would affect the results.

The characteristics of the materials used to make the concrete used to cast the specimens are given in Table 1 for ENIG and INSAT, respectively. Bars in both cases have been cut from FeE500 steel deformed bars with a nominal diameter $8 \mathrm{~mm}$ and a yield strength $\sigma_{e}=564 \mathrm{MPa}$

During the test, a pulling force was applied with the help of a conical jacket and a hollow jack cylinder usually used on construction sites to apply pre-stressing forces on wires. A reaction frame was created to allow the jack and the specimen to be adequately positioned, as seen in Figure 5. The value of the ultimate force was obtained from the readings of a manometer connected to the jack. Plain concrete cylindrical specimens (diameter $16 \mathrm{~cm}$, height 32 $\mathrm{cm}$ ) were molded and tested under axial compression at the same age that the APULOT tests were performed, in order to obtain the

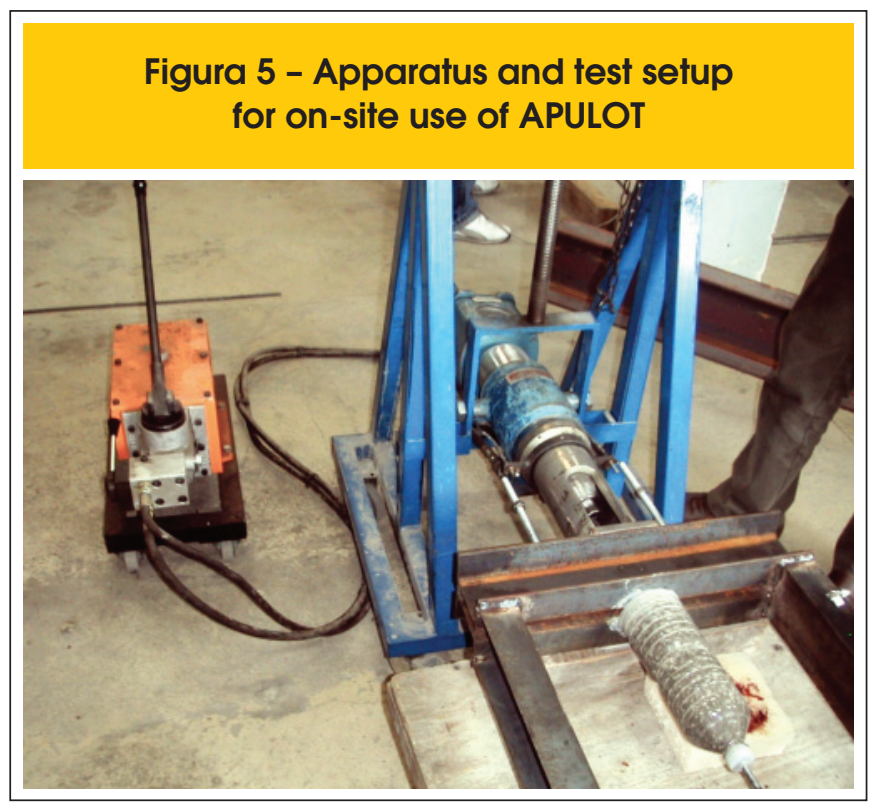

pair of results necessary to plot ultimate bond strength and compressive test graphs. APULOT specimens were tested at 3, 7 and 14 days, to check if the bond/strength relationship would still be the same at early ages. This is an important

\subsection{Results}

The results of the tests performed at ENIG and INSA are summarized on table 2. Analyzing the data it can be noticed that two very different ranges of compressive strength were obtained at ENIG (7-8 MPa) and INSA (23-27 MPa), which was a desired condition to check if the estimates of compressive strength from bonding tests will be sound for a wide range of concrete strength levels.

All the failures obtained on both places were of the slipping mode type, as expected. Therefore, all data was added to the graph relating ultimate bond stress and compressive strength shown in Figure 2 , resulting in the new graph seen in Figure 6.

As can be seen in Figure 6, the new sets of results fit well with the rest of the data collected, but it can be noticed that the ENIG results tends to cluster together, indicating a possible lower limit for the relationship. Data from tests performed at different ages fit well with the rest, proving that the APULOT test can be performed, with good results, at an age as early as 3 days, if necessary.

Figure 7 shows an estimate model derived by using linear regression to fit a straight line at the data. The very good fitness of the correlation line shows the great promise of this kind of approach and validates the idea of using the APULOT test in concrete quality control.

Of course, the estimates obtained using the correlation line from Figure 7 would have to be slightly reduced to ensure that the presumed concrete strength values would be on the safer side.

This adjustment would need to be larger because, in some points, there is a considerable variation of bond stresses registered for a certain level of compressive strength. To improve the results it is considered necessary to adjust and consolidate test procedures, because varying test conditions are sources of increased variability. For example, as expected and registered in table 2, when the embedment length increases, the bond stress will naturally rise, for a given concrete strength. Both results are plotted against the same concrete strength in the graph.

The absence of a standard test allows this kind of noise to affect the data gathered, which was obtained from different and non-related studies. The adoption of standard specimen geometry and test conditions will naturally provide more precise data correlations, which in turn will increase the reliability of the strength estimates. The APULOT group is currently working to achieve this aim. 


\section{Table 2 - Feasibility tests, results}

\begin{tabular}{|cccccc}
$\begin{array}{c}\text { specimen } \\
n^{\circ}\end{array}$ & $\begin{array}{c}\text { test } \\
\text { location }\end{array}$ & $\begin{array}{c}\text { age, } \\
\text { days }\end{array}$ & $\begin{array}{c}\text { Embedded } \\
\text { length, in. } \\
(\mathbf{m m})\end{array}$ & $\begin{array}{c}\text { mean compressive } \\
\text { strength } \mathbf{k s i}\left(\mathbf{N} / \mathbf{m m}^{2}\right)\end{array}$ & $\begin{array}{c}\text { ultimate bond stress } \\
\mathrm{ksi}\left(\mathrm{N} / \mathrm{mm}^{2}\right)\end{array}$ \\
\hline 1 & ENIG & 3 & $5.27(135)$ & $0.983(6.78)$ & $0.609(4.20)$ \\
2 & ENIG & 3 & $5.27(135)$ & $0.983(6.78)$ & $0.699(4.82)$ \\
3 & ENIG & 3 & $5.27(135)$ & $0.983(6.78)$ & $0.788(5.43)$ \\
4 & ENIG & 7 & $5.27(135)$ & $1.175(8.10)$ & $0.716(4.94)$ \\
5 & ENIG & 7 & $5.27(135)$ & $1.175(8.10)$ & $0.788(5.43)$ \\
6 & ENIG & 7 & $5.27(135)$ & $1.175(8.10)$ & $1.111(7.66)$ \\
7 & INSAT & 3 & $3.12(80)$ & $2.186(15.07)$ & $1.469(10.13)$ \\
8 & INSAT & 7 & $3.12(80)$ & $3.414(23.54)$ & $1.255(8.65)$ \\
9 & INSAT & 7 & $3.12(80)$ & $3.414(23.54)$ & $1.416(9.76)$ \\
10 & INSAT & 7 & $3.12(80)$ & $3.414(23.54)$ & $1.504(10.37)$ \\
11 & INSAT & 7 & $3.12(80)$ & $3.414(23.54)$ & $1.577(10.87)$ \\
12 & INSAT & 7 & $3.12(80)$ & $3.414(23.54)$ & $1.433(9.88)$ \\
13 & INSAT & 7 & $3.12(80)$ & $3.414(23.54)$ & $1.684(11,61)$ \\
14 & INSAT & 7 & $3.12(80)$ & $3.414(23.54)$ & $1.899(13.09)$ \\
15 & INSAT & 14 & $5.27(135)$ & $3.880(26.75)$ & $1.971(13.59)$ \\
16 & INSAT & 14 & $3.12(80)$ & $3.933(27.12)$ & $1.540(10.62)$ \\
17 & INSAT & 14 & $3.12(80)$ & $3.933(27.12)$ & $1.684(11.61)$ \\
\hline
\end{tabular}

\section{Figura 6 - Updated bond stress/compressive strength relationship data gathered in the current study}

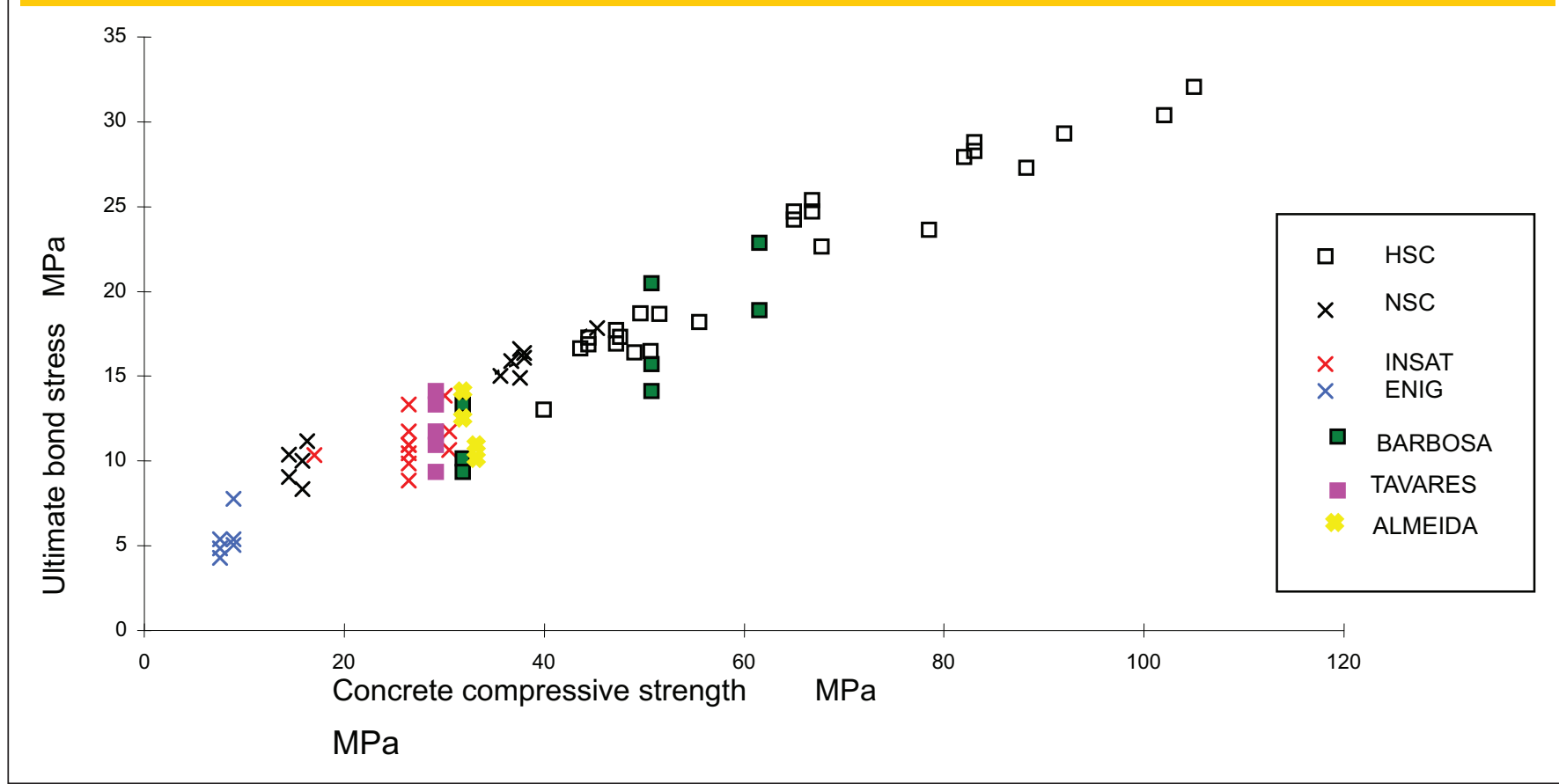


Figura 7 - Correlation line between ultimate bond stress and concrete compressive strength correlation, obtained by linear regression with a $R^{2}=0.9555$

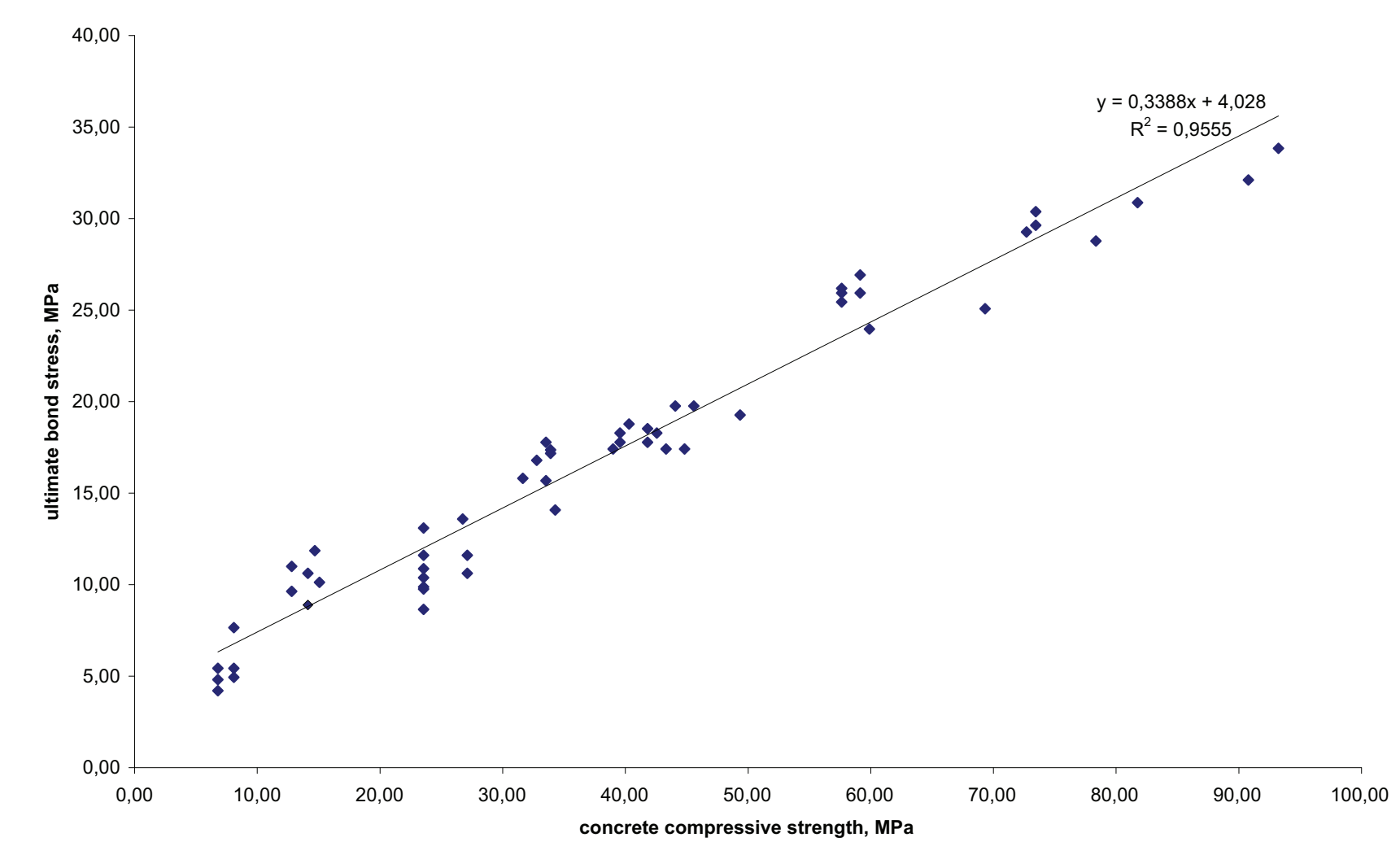

\section{Conclusions}

Quality control of structural concrete is a compulsory stage in the building process, which have been conducted for decades solely by means of axial compression tests. This procedure, which has stood the test of time, is not exempt from significant drawbacks and its results have been the subject of much discussion lately. Therefore, it would be useful to have other independent ways to assess concrete strength, which could be used in conjunction with traditional concrete compressive tests to improve quality control. Given the fact that compressive strength has been found to be closely and consistently related to bond strength, an interesting alternative would be to develop a standardized bond test able to provide accurate concrete strength estimates. This notion has fostered the formation of an international research consortium to test, develop and implement the Appropriate Pull-Out test (APULOT) proposed by Lorrain.

The paper describes two series of tests performed using the APULOT method in France and Tunisia. The results indicate that, when performed in an appropriate way (that is, controlling the failure mode to force bond-slip behavior), bond tests are found to be reliable enough to provide compressive strength estimates. Even with the changes in age of test and embedment length, the data gathered had little scattering and was consistent with previous data collected from the literature.
The full database, including the data from the tests and the previous data collected from the literature, was used to define a very well-fitted correlation line between ultimate bond stress and concrete compressive strength. The estimates made using this preliminary model were shown to be reasonably accurate and the underlying variability can be further reduced with the adoption of standard practices for the test. This aspect is being currently investigated by the APULOT group.

The work clearly demonstrates that the principle proposed is sound and reproducible. Therefore, it justifies the continuation of the efforts to develop a strategy for incorporating results from simple, quick an on-site bond tests as subsidy for reinforced concrete quality control.

\section{References}

[01] Instructions relatives à l'emploi du béton armé, Circulaire du 20 octobre 1906, in Annales des Ponts et Chaussées tome XXIV 1906, 4ème trimestre, Paris.

[02] CEN. Testing hardened concrete. EN 12390, 2009.

[03] ABNT. NBR 5739 Concreto: Procedimento para moldagem e cura de corpos de prova. Rio de Janeiro, 2003.

[04] ACl. Guide for Obtaining Cores and Interpreting Compressive Strength Results. ACl 214.4R-03, 2003. 
[05] Rehm, G. The Basis Principles of the bond between steel and concrete, Cement an d Concrete Association, Cj.134(9/68), London translated from the German Publication No 138 of the Deutscher Ausschuss für Stalhbeton: "Uber die Grundlagen des Verbudes zwischen Stalh und Beton", Berlin 1961.

[06] CEN. EUROCODE 2 P 18-711-3

[07] BAEL.[Règles techniques de conception et de calcul des ouvrages et constructions en béton armé suivant la méthode des états limites], 1991 rev 1993 CSTB

[08] ABNT, 2003. NBR 6118, Projeto de estruturas de concreto - procedimento Rio de Janeiro: ABNT, 2003.

[09] Comité Euro-international du Béton - RILEM/CEB/FIP Recommendation RC6:"Bond test reinforcement steel - Pull Out Test." Concrete Reinforcement Technology, 1983.

[10] ASTM. Standard test method for comparing concretes on the basis of the bond developed with reinforced steel, C 234, 1991; Philadelphia.

[11] RILEM/CEB/FIB. Bond test for reinforcing steel: 1-Beam test (7-II-28 D). 2-Pull-out test (7-II-128): tentative recommendations. Materials and Structures, v.32, n.6, 1973; p.96-105.

[12] ACl. Bond and Development of Straight Reinforcing Bars in Tension, ACl 408R-03, 2003.

[13] Lorrain, M.S., Maurel, O., Hamouine, A. Résistance à l'arrachement d'armatures à haute adhérence de haute nuance ancrées dans du béton de hautes performances, Annales du BTP, n5, novembre 1997.

[14] Tavares, M. E. Ensaios de arrancamento em barras nervuradas. Seminário de doutorado, COPPE/ UFRJ, 1997.

[15] Barbosa, M.T.G. Evaluation of the behavior of the bond in ordinary and high strength concrete. Doctoral Thesis, COPPE/UFRJ, 2001. (in Portuguese)

[16] Almeida Filho, F.M. Contribution to study of the bond between steel bars and self-compacting concrete. Doctoral Thesis, Universidade de São Paulo, 2006. (in Portuguese)

[17] Vale Silva, B, Investigação do potencial dos ensaios APULOT e pull-out para estimativa da resistência a compressão do concreto. Dissertação de Mestrado FEIS/UNESP, 2010.

[18] Makni, M., Daoud A., Lorrain, M.S., Karray, M.A. Essai d'arrachement et contrôle de la qualité du béton sur chantier » Colloque MS $^{2}$ Matériaux Sols et Structures, Hammamet, 163 mai 2009; Tunisie.

[19] Vale Silva, B., Santana, I.V., Barbosa,M.P. Silva Fuilho, L.C.P., Lorrain, M., Bond test "APULOT": Experiments on the influence of format in PET BOTTLE I the ultimate bond stress, XXXIV Jornadas Sudamericanas de Ingenieria Structural, San Juan-Argentina, 2010. 